\title{
Diffraction or Delusion: An Ethnoarchaeological Investigation to the Magico- Medicinal Practices (MMPs) of Mayong, Assam
}

\author{
Rakesh Kumar $^{1}$ and Dr Shahida Ansari ${ }^{2}$ \\ ${ }^{1}$ School of Humanities, National Institute of Advanced Studies, Bangalore \\ ${ }^{2}$ Department of Archaeology, Deccan College Post Graduate and Research Institute, Pune \\ Email: kumarrakesh9709@gmail.com; rakeshkumar@nias.res.in
}

\begin{abstract}
Magic and Medicine were intertwined in ancient civilization and are acutely embedded in folk healing culture currently. The Indigenous Knowledge (IK) of healing as cultural intangible heritage have been widely discussed by anthropologists, historians and fictional novelists. But within archaeological discourse, these practices have been neglected by the community of archaeologists. Here, the focus has been placed to the ethnoarchaeological investigation of the Black Magic (BM) practices of Mayong, Assam through the re-elucidation of its the material culture and symbolism used during Magico-Medicinal Practices (MMPs) or Magical Practices (MPs). Whereas, the fundamental objective is to critically review the existing archaeological as well as a socio-cultural approach to IK of Magico-Medicinal healing, in which MMPs and MPs have been diminished to the extent of social exclusion.
\end{abstract}

Keyword: Indigenous Knowledge; Magico-Medicinal Practices; cultural intangible heritage; ethnoarchaeological, material culture and symbolism.

\section{Introduction}

Magic has been defined subjectively in various cultural context because of the constant variation in firm beliefs. For the early man, religion and magic were almost similar and were shaped by their premier form along with human existence. James Gorge Frazer (1890) in The Golden Bough, regarded magic as to be the antecedent to the worship of God. Whereas, Bronislaw Malinowski (1940) traces the origin and function of magic and religion in the situation of emotional stress like crises of life, a lacuna in pursuit, death and initiation in tribal mysteries' (Malinowski 1940: 67). MPs are sometimes also defined as 'technique of religion' (Kalita 1992: 6). Magic can be broadly categorised into Black and White based on the intention of practices. The MPs who are intended to harm somebody considered as BM and whereas MPs intended to heal somebody is considered a White Magic (WM).

MPs or MMPs are an integral part of the discourse on folk knowledge and culture. Even Codified Medical Systems like Siddha and Tibetan Medicine also gives importance to magic ( Sébastia 2013; Christopher 2012). For example, Tibet has a tradition old folk religion called Bon. It believes in animism ${ }^{1}$, ancestral

\footnotetext{
1 The religious belief perceives all things-animals, plants, rocks, rivers, weather systems, human handiwork and perhaps even words-as animated and alive. It is contrast to
}

worship, sprits manipulation, mystic rituals, sacrifice for gods and spells. Their beliefs in Bon religion have very much influenced the Tibetan Medical practices (Bellezza 2005). In the information age (Manuel 1998) magic, in the form of practical art, is hemmed in techniques like spells and rites handed over by 'direct filiation' to a cohort from generation to another (Kalita 1992: 6) and religion, a self-constrained act, centred on the various tenant of beliefs, opens equal access for all at its nascent stage, are considered as confused ideology by common man. But to the early man or in tribal and folk community faith in spirits, ghosts, witches, tribal godfather and vision of future life are the 'secondary supernatural reality' (Malinowski 1940: 42; Rosengren 1976:667-85).

The antiquity of MMPs and MPs goes back to the Vedic Period. Atharva Veda (900BCE-700 BCE) is considered as significant literary evidence for MMPs and MPs. As far as archaeological evidence for the belief MMPs and

organised religion and practiced by indigenous people (Hicks 2010:359; Bird-David 2000).

2 'a combined typology for symbol systems and corresponding standardized activities based on two main distinctions, where the substantive distinction is valid mainly for the symbol level and the functional one mainly for the activity level. Where the distinctions are more or less inadequate, they are sometimes replaced by others, which may be empirically correlated with the originals' (Rosengren 1976: 672) 
MPs are concerned, it could have been traced back to the Palaeolithic period in the firm belief in animism (Hicks 2010:359; Bird-David 2000). For example, Upper Palaeolithic rock art of six-armed chakra along with animal-headed spirit with Puthi from Pachmarhi hill, Madhya Pradesh (Fig.1) can be associated with the belief in MPs (details are in Discussion section) or feet chopped burials of Jorwe culture from Inamgaon (Fig. 2) are explained as some kind of belief in spits and afterlife (Dhavaliker et.al. 1971). Andrew Clifford (2012: 50) in his book The Geologic Model of Religion has proposed a hypothesis that red ochre colour was certainly used for the practice of sympathetic magic and can be interpreted as the blood of earth needed for the sustenance in afterlife. According to his description the other example of homoeopathic ${ }^{3}$ magic practices i.e. like-for-like and like-make like (Clifford 2012: 50) in Palaeolithic period in can be attributed to use of ochre colour in burials practices of Neolithic Gufakaral, Kashmir.

Since ancient time (starting point is problematic to track) the magical beliefs and practices are ubiquitous in Mayong, Assam ( earlier it was the abode of the agropastoral ethnic population but currently it is an agrarian economy village). The belief in animism, symbolism, superstitious belief still plays an important role in village socio-economic life. It is considered as an epicentre for the widespread tantric and magical practice in India. The people of this village have deep faith in the traditional occult or folk healing practices. The historical, literary, oral and ethnographic data suggest that the practice of black magic has been present since the earliest human culture stared residing in the confined landscape of Mayong. But the archaeologist is cautious to support the statement in absence of proper archaeological stratified data and detail archaeological exploration. Now, these beliefs have been transformed into magico-medicinal practices. In some cases, practitioners still claim that they can manipulate the supernatural power (who use to control their fate) and circumstances in the world where they were granted little medical facilities and inadequate socio-economic power.

There are several kinds of mystical practices are prevalent in Mayong explicitly aeromancy (prediction of weather), augury ( forecast from the behavior of bird), anthroposophy (prophecy by facial feature), belomancy (forecast by arrow i.e. ban), bletonism (prophecy by water), catoptromancy (prediction by mirrors), Ichthyomancy (prediction by fishes), sciomancy (prediction by shadows or ghosts), tephromancy prediction (prophecy from sacrificial ashes), xylomancy (prediction by dry sticks) and psychometry (prediction by handling an object) (Kalita 1992: 16-20).

\footnotetext{
3 James Frazer (1980) has been categoried magic into 'imitative', 'contagious' and 'homeopathic'.
}

\section{Methods}

This particular research work is based on the ethnographic study of Mayong. It also includes some archaeological theories like post-processualism to describe to understand the symbols used MMPs and MPs. and archaeological method of exploration. The recovered archaeological artefacts and sculpture has been also taken into the consideration for batter understating. The texts and content analysis method have also used during the investigation. The ethnographic method of data collection includes the open-ended semi-structured questionnaire and responses from both the healers/practisers and healed/common people to lager picture of understanding. The sampling system involves stratified random sampling and convenience sampling method.

\section{Mistry of Magic in Mayong}

\section{a. Geographical Placement and Short History of Mayong}

The northeastern part of India is regarded as ' $12^{\text {th }}$ biohotspot of global scenario'. These states are having inhabitants of more 130 major tribal communities out of 427 tribal communities found in India. They are living in a harmonious relationship with the environment (i.e. physical geography) and consciously creating a healthy ecosystem for the development of the wealthy economic structure. Their cultures are parallel and competitively prevailing with its flora and fauna. Out of the 130 tribes, $70 \%$ of tribal populations rely on their environment for herbal medicine from generations (Nanda 2014).

Mayong, the Village comes under Marigaon district of Assam (one of the states from the northeastern part of India). Before the division of new political boundaries (before 1947) it falls under the Kamapitha (one of the four geographical divisions of ancient Kamrupa ${ }^{4}$

\footnotetext{
${ }^{4}$.Kamrup or Kamarupa is the modern region situated between two rivers, the Manas and the Barnady in Western Assam. It is congruent to ancient "Kamapitha " or "Pragjyotisha Bhukti". In medivial period is called as "Sarkar Kamprup". Currently equated with modern "United Kamrup District"( Garg 1992: 428; Goswami 1998: 25; Choudhury 1959 458). There is no unanimous opinion about the antiquity of Kamarupa. The Kamrupa and northeast region has no mention in Ashokan record ( $3^{\text {rd }}$ cen. BCE) (Nath 1968:4). First dated mention come from periplus of the Erythraean Sea $\left(1^{\text {st }}\right.$ cen. CE) where it describes a people called Sesatea (Casson 1989:241-43). The name Kamrupa is also mentioned in Ptolemy's Geographia $\left(2^{\text {nd }}\right.$ cen. CE) as the of region Kirrhadia and in Arthasastra $\left(1^{\text {st }}\right.$ cen. CE) as Lauhitya (Sircar 1990:60-61; Cauhduri 1985:2). The earliest mention of a kingdom comes from the 4th-century from Allahabad Pillor Inscription ( $4^{\text {th }}$ cem CE) of Samudragupta that calls the kings of Kamarupa (Western Assam)
} 
(Assam) namely Ratanapithas, Kamapitha, Swarnapitha and Saumarrapitha) and had throttlehold of both Hindu and Buddhist tantrism between $8^{\text {th }}$ to $15^{\text {th }}$ cent. CE. It is still regarded as the epicentre of black magic and witchcraft (Nath 1948:6) (Barua 1966:21). The region comes under dense forest area and situated beside the Pobitora wildlife Century. Mayong is surrounded by small hill and hillocks from the north, known as Kachoxila (tortoise shaped stone). The river Sonai and Pakaria flow from east to northwest of the village. On the extreme south, the river Kalong flows from the northwest towards the west up the confluence of river Brahmaputra (Fig. 3). The geographical placement of Mayong might be the prime factor of the formulation of distinctively practised culture. Though currently, it shares a porous land route connection with Bangladesh (Fig. 3).

It is traditionally known as Mayang (Sanskrit word in Sveta Upanisad) which implies the Yoni or Prakriti or Mahamayang which is the prime deity over nature, Demigods and Goddesses. Another opinion regarding the origin of the name stated that the name Mayong is derived from the word Maya (an illusion) (Kalita 1992). It is also narrated in oral stories that the Mayong is named after an evil spirit Maya along with the evil spirit bvadhi. (Sharma 1981:56 and Bordoli 1996:69).

Several dynasties have ruled or control over Assam in Mayong such as Gupta $\left(4^{\text {th }}-7^{\text {th }}\right.$ Cen. CE) Pala (8th -12 th Cen. CE), Ahom (1228-1826) and Koch (1550-1949). Therefore, their courtly faith in different religious sects like Mahayana, Theravada and Vajrayana Buddhism, Shaivism, Shaktism, Vaishnavism and Satsana Pi (folk animist tradition currently Practiced by Lao, Tai Ahom, Lao Isan and Thais of Thailand). These faiths in different sectarian-based religious practise having transformed the earlier structure of magical practices in Mayong (Shriayama 2006: 622).

\section{b. Structure of Black Magic in Mayong: Past and Present}

As discussed above, Mayong shaped distinctively by its geography and defined evidently by groups of various people tribal and non-tribal people in a composite manner to create a complex Cultural Landscape ${ }^{5}$. Therefore, the assorted MPs of Mayong is a by-product heterogeneous religious belief. The village has a tradition of gaon bhura (baij lojha/bez i.e. physician/occult therapist) for the treatment of all the diseases through herbal medicine and chanting or intonations of mantras or MPs. They are sometimes equated with the Vida too.

and Davaka (Current Nagaon district Assam) (Sarkar 1992:21$35)$.

${ }^{5}$ Cultural Landscape represent the combined work of Nature and man (UNESCO 2012).
The Padshah Buranjii, an Ahom chronicle, mentioned about prevalent credence that Assamese women adapt in the art of harmful charm. Alamgirinama recorded that in 1337 CE Muhammad Shah sent an army troop of one lakh (100000) soldiers and horseman to Assam but army perished in the land of witchcraft not a trace of them was left. Another account of Shihabuddin, a writer came with Aurangzeb's commander Mir Jumla, talked akin to Alamgirinama by mentioning that people of Hindustan used to call the inhabitant of Assam sorcerers and magician and consider them outside the human species (Das 1972: 41).

The credence of BM and WM were prevalent among all groups like a literate or illiterate, group of tribal or nontribal society, and every economic status people in earlier days. But the tradition of black magic has gradually loosened its grip among contemporary society as a controller of fate. Currently, BM in Mayong is only restricted to the practice of magic for MMPs and confined to the hand of a cohort bej/ojha. Current society accepts BM practices as an awful output of ancient mysterious tradition and considers it as a sinister veneration of dreadful supernatural power.

The tribal and non-tribal folks of Mayong such as Garo, Miri, Naga, Bodo and Brahman, Kalita, Vaishya etc. separately and simultaneously believe in oculist practices and evidently influenced by different sectarian belief viz. the Karbi tribe follow the Christianity because a large portion of Karbis is converted to Christianity. It is also important to note here that no priest/monk is required to chant mantras. Any capable sorcerer belonging of any caste, race, religion and region can enchant the mantras and get the desired result. The inherent practices of enchanting mantras have lots to appeal since past unknown. Which reflects in the regular habit of people in Mayong by depending on magical beliefs for daily chores.

The unexplored treasure of peculiar form of magical belief makes Mayong the capital of BM and a secret abode for some rare magical tricks. This may look like aberrant practices in the backdrop of the modern era but substantial enough for indulging individual to reconsider the existence of BM and MMPs in the form of folk Knowledge of indigenous people. Like, fortunetelling through Korris (Cowrie seashells) (Fig. 4), augury practices and palmistry. There are many such great affliction with mystical perplex including Mohini (attracting someone towards oneself by mantras), Basikaron (controlling other person by magic), future forecasting through the broken piece of glass, enchanting handful of plants with spell or mantras during bejali practices (MMPs performed by the $\mathrm{bej} / \mathrm{bez}$ ) for the relief from sufferings and the curbing of back pain the with the utterance of some magical mantras and use a copper dish to trace the proper location of the pain are also quite widespread in this region (Fig. 5). 
The mantras used by the bej/ojha during the charms and spells are might be the legacy of Atharvavedic tradition. But due to the commotion and influences of various tantric and religious philosophies were prevalent in Mayong, mantras must have undergone various changes. Therefore it is difficult to identify the original nature of mantras. The mantras are mostly are written in prose form and the Chandas (used is poetic verse ) are fully absent. This might be a purposeful attempt to restrict into a handful of cohort sorcerer and hard to remember. But quite a few are transcribed into poetic verse also. The language of the mantras of ancient manuscripts is old Assamese and the script is Kithali. Large numbers of mantra puthis, written on various materials, eloquently present the portrayal of ancient Assamese mantra used as a medical remedy for various physical or mental illness (Das 1972:43 and Barua 1967) (Fig. 6).

\section{c. Magic and Religion in Mayong}

Though Malinowski (1922, 1931, 1935, 1936, 1946) has separated Magic from religion and science in Mayong magic and religion are complementary to each other. In so far as devout in deities are concerned shrines of Shiva, Shakti and Ganesh are conspicuous in this village. For example, there is also a twin rock-cut engraved of Har-Gaudi and besides that a Ganesha stone sculpture inside the pond. The intentional engraving of deities on selected places can be interpreted as the mystical creation of Ganesh (as a doorkeeper) by Gaudi while going for a bath (as mentioned in the Shiva Purana) (Fig 7). The deities (Har-Gaudi and Ganesha) are venerated by Koch people. The other example of the mystical association of religion with magic can be seen in an enormous size Ganesh entwined serpent across the body at Boha temple (why with the mystical association has been separately discussed in the discussion).

The evidence of Buddhist tantrism can be also easily identified by the presence of Panch Pandava temple. The sculptures of this temple are known as five meditative Buddha (namely Bairrachana, Akashobhaya, Ratna sampala, Amitabha and Amoghsida) along with the lady image on the door sanctum. The five meditative Buddha are used to equate with disciples of 'Darikpa' alias king Indrapala, the father of king Gopala, the follower of Vajrayana philosophy. It is again important to note that the Mantrayana sect was very much prevalent in this region between $10^{\text {th }}$ to $12^{\text {th }}$ century CE, which support the association of Panch Pandava temple with the tantric stimulus (Singh 1980: 57; Barua 1967).

As discussed earlier magic and religion are not separate to each other and in most of the case, popular reverent God and Goddess are being praised by sacrifice for the success of MPs. For example, Shakti shrines are more in number (in this province) and known as Than. The most popular one is Kamakhaya, but every village in the geographical vicinity of Mayong has a shrine of the folk mother goddess in various form. Kesaikhati ${ }^{6}$ (Fig. 8), Bhagawati, $\mathrm{Ai}^{7}$ are the names of such thans. Some of them are very popular for sacrifice like Kesaikhati (literal meaning one who eats raw) and $\mathrm{Ai}$ than of Mayong are few among them. As per oral narrative (collected during the ethnographic survey among villagers), the Kesaikhati and Ai thans times were very popular for human sacrifices were predominant in earlier times (Singh 1980). The villagers claim that the last human sacrifice was conducted in 1975AD. The important thing to understand here is that the religious belief in the folk God and Goddesses were no lesser than the mainstream Hindu or Buddhist deities. The Karbis of Burha Mayong believes that they are protected by Kesaikhati. The deosal and the sorceress of this village are also used to offered puja to this shrine to make their mantras more efficient (Kalita 1992).

Other than the identified and acknowledged venerated divinities, people of the geographical vicinity of village Mayong are actively involved in the reverence of unknown local mystical deities contextually associated with witchcraft and sorcery practices. An unidentified rock-cut sculpture of the goddess having the human maxilla in her left hand and a parrot in her right hand is recovered from Ambari $\left(7^{\text {th }}\right.$ to $12^{\text {th }}$ cen. CE) archaeological site (about $30 \mathrm{~km}$ from Mayong) (Fig. 9). The iconographic features and Aayudha (possesses material) suggests sculpture is associated with mystical activities. According to the encryption of necromancy and oral tradition, the parrot is used as a symbolic representation of the victim in witchcraft practices and the Daayans (the female counterpart of the sorcerer) or sorcerers are used to kill that parrot after complication of the adoration of his or her reverent god and goddess in the hope that the way parrot will suffer and die he/she sorcerers will be able to harm the prey in an analogous way. The other similar kind of iconographic representation has been also unearthed from the same Ambari Site $\left(7^{\text {th }}\right.$ to $12^{\text {th }}$ cen. CE). But in this sculpture can be also seen in another stone sculpture (also recovered from Ambari, Assam) but in this representation, the parrot is replaced by a doll (sometimes the doll is mentioned as Voodoo doll ${ }^{8}$ ) and the deity's physical anatomy is sculptured as a yogi (Fig. 10). The use of a doll in sorcery is a universal phenomenon to transmit negative energies to victims. One such use of a doll (made up of cow dunk and ash) has been found by the reported by the author from the bank of river Mula-Mutha, Pune in 2017 during exploration for comparative study (Fig. 11). Some other unidentified stone sculptures are also recovered from

\footnotetext{
${ }^{6}$ The shrine of seven swords of forefather tied up the right to the wooden post, similar to sacrificial post.

${ }^{7}$ The shrines are in the form of Sacrificial Pitta or Yoni pitha.

8 A type of doll into which pins are inserted and used for magical tradition in many culture across the world (Hutton 1999)
} 
geopolitical boundaries of Mayong, Assam. One such example is a ten-handed basso-relievo sculpture of a mother goddess excavated from Ambari, Assam, belongs to the period of 10th -12 th Cen. CE. As per her physical appearance and iconographic feature i.e., the holding of mantra puthi (as aayudha) in her left hand can be associated with the practices of witchcraft and mystical awe (as per textual description) (Fig. 12). Along with the deities, various Yoni Pittas and Serpent Sculpture are worshipped by the indigenous people of Mayong. People of Mayong are also used to worship Kali and Durga (the incarnation of Shakti) by the annual sacrifice of a goat, buffalo and in ancient time by human sacrifice. One sculpture of tribal form has been also recovered from Ambari, Assam (Fig. 13 \& 14).

Sacrifices are universal, inseparable and integral part of the witchcrafts performances. BM practices of Mayong also has numerous tradition of sacrifices e.g. the Thal puja (offered in the jungle by sacrificing of fowls and pigeon), the tortoise sacrifices (offered to Kesaikhati), the cattle sacrifices and the human sacrifice (Das 1972: 41). Even today the sacrifice of pigeon, goat, tortoise and fowls are ubiquitous. Along with the abovementioned cult, the Ratikhowa (propagated by 'Gosains'), a corrupt form of Vaisnavism (called kalSamithti) is also prevalent in this region (Kalita 1992:278). The presence of the horned buffalo head and cattle femur as an archaeological data (Kept in Mayong Mystical Museum) corroborate the statement that animal sacrifice was very much prevalent in reverence of God (Fig. 19).

\section{d. Symbolism, Material Culture, MPs and Mayong}

Humans are unique in communicating via symbolic language from other organisms and delineated as 'symbolic animal' (Cassirer 1987: 48). Symbols are the materialised depiction of an abstract ideology in the object (De Marrais et al. 1996; Robb 1998, 1999). And, 'Once materialized, these symbolic objects can be controlled and manipulated in much the same way that any other non-symbolic object can and the manipulation of a material symbol can act to change the underlying meaning of the same symbol' (Fogelin 2017). Magical practices have governance of symbolic medium. The structure of occult practice is similar to the poetic language but it involves non-verbal sign language instead of poetic verbal language (Cassirer 1987). Symbols in MPs are usually in from of language like a vibration in the rhythm and musicality and few cases graphical symbols are also used. The symbols such as swords, magic band, the crucible concentric circle, chakra (wheel), Padma chakra and chakra with other weapon or instrument like trident, stick and bone are used as an instrument for charming and enchanting (Fig. 15).

There are two symbols of six armed chakras has been identified (during exploration) in Mayong. One is plain six-armed chakra, engraved on the side of Yoni Kund in Mayong, Assam (Fig. 16) and other is six-armed chakra over the Padma (lotus) along with the Trishul (trident) and Haddi (bones) at Kachoxila (tortoise shaped stone) which shows its association with tantric practices or oculist performs. The stylistic feature of chakras is identical with Upper Palaeolithic rock art from Pachmarhi hill, Madhya Pradesh (as discussed above) (Fig. $1 \& 16$ ). The portrayal of chakra on the part of Yoni Kund suggests that it mus would have been used during the BM and tantric siddhi, The Yoni tantra and Kalika Puran conferred the importance of reverence of Yoni for siddhi (penance) in Shaktism as well as in Shivaism. Various Symbolic Yoni Pittas are observed during the exploration of the Mayong and geographical Vicinity.

Materials in MPs are used as a medium of adoration and appeasement object for divinities. Sometimes materials are used as a symbolism of cosmic energy and a medium of diffusing and transferring vibrant opposite energy to the other person. The material in ritualistic performs fuses the original context and create an atmosphere of vague reality. For example, during the possession sword and sound can be seen as an enhancement and way of reverence. Swords have multiple uses, on one hand, it is interpreted as a tool for offering sacrifice whereas on the other hand it is used as a medium of possession and sometime deity itself (as in case of Kesaikhati and Ai thans) (Fig.17). In some of the cases the objects such as a pendant, yantras and stones were also used as a protective power from impairing evil spirits and against the negative energies (Fig. 18). Uses of such kinds of objects and practices of possession are still prevalent in this area.

\section{Ethnoarchaeological Investigation and Antiquity of MMPs or MPs in Mayong: A Debate}

Every communities or culture have two clearly distinguishable domains, the sacred and the profane (Durkheimian 1915). In other words, the domains of magic and religion, regarded by the narratives as sacred. This domain depends on traditional acts and observations which is carried out with reverence and awe, hedged around with prohibition and the special rule of behaviour, and always associated with the beliefs in supernatural forces especially those of magic and paranormal activities with ideas about spirits, ghosts, dead ancestors and god. While the domain of profane discussed as science. Which depends on the careful observation of natural process, power of reasoning and confidence of the observer and also on the firm belief in the regularity natural process. (Malinowski 1940:1). The oriented belief in the domain of sacred coupled with confidence in reasoning capacity might lead human to imagine the outer world in his own image (Malinowski 1946:2). The historian Julien Ries (1994) in The Origin of Religion, has described the behaviour of creating a culture through the imagination in symbols as 'homosymbolicus' i.e. men's grasping 
capacity of the invisible by means of visible (Ries 1994:6). The traces of the 'homosymbolicus' capacity in archaeological record always helps in reconstructing the journey of an organized faith originated from symbolics and practised as religious/magical activity over the time of two-million-year (Insole 2004:24). For example, ' $a$ Kalibangan cylinder seal shows a woman flanked by two men who hold her with one hand and raised swords over her head with other; this may represent a scene of human sacrifice or the evidence suggesting ritualistic practices comes from the 'fire alter' found on citadel mound at Kalibangan' (Singh 2009) has assisted in the understanding the puzzle of human sacrifice and finding out the antiquity of mystical beliefs and ritualistically performed in contemporary culture.

MMPs and MPs are the amalgamations of architecture, offerings, and other material traces with ritual and religious practice (as I stated earlier). Therefore, it is very much needed to understand these practices beyond mare ethnohistorical understanding as to the religious doctrines, beliefs and myths. The archaeological investigation of folk religion required proper contextualization for the bifurcation between religious and non-religious artefacts because the idea of religion and ritual are integral to daily life activities among the folk community. The practice-oriented understanding of ritual arguing that a ritual is a form of human action that leaves material traces as an enactment of religious principles or myths. 'Ritual practices are necessarily patterned and repetitive; producing material signatures that are readily (and uniquely) open to us as archaeologists for investigation. These interpretable traces are further structured by their spatial relationships, their location within the landscape, their orientation, and indeed, their relationships over time, (Howey and O'Shea 2009:193-201). For example, the purpose of depicting chakra symbol (found in an archaeological context in Mayong Assam and Upper Palaeolithic Pachmarhi hill, Madhya Pradesh) has been interpreted in association with mystical activity ( as discussed above) because of the reparative nature those symbol in current mystical activities (found in the ethnographic study of Mayong).

Arguably, the antiquity of MMPs and MPs goes back to the Palaeolithic culture in from of animism practices. As discussed earlier in this section, the beliefs in MMPs and MPs have travelled a long journey from symbolic to religious. In India generally, the belief in MPs can be traced backed to the Upper Palaeolithic period and was present in almost all subsequent cultures like Neolithic, Chalcolithic, Iron Age etc. (As examples are discussed in above sections). The antiquity of MMPs and MPs in Mayong went back to the $7^{\text {th }}$ to $8^{\text {th }}$ cen. CE based on corroborated stratified archaeological shreds of evidence like sculptures (mentioned above) recovered from the excavation of Ambari, Assam (Dhavalikar 1973; ASI Guwahati Circle 2008-09). Though there is no unanimous chronology of the site is available due to the presence of various foreign ware like Arretine and
Roulleted ware $\left(1^{\text {st }}-2^{\text {nd }}\right.$ cen. CE), Chinese celadon ware (10th -12 th cen. CE), and Green glazed ware (16th -17 th cen. CE). Whereas the Mantras used for MMPs in Mayong claims their association with Vedic tradition especially Atharva Veda (900BCE-700BCE) but in contrary, linguistic examination of mantras and manuscripts shows the connection with old Assamises language and Kathali Script which roughly goes to medieval period i.e. during Ahom (1228-1826) and Koch (1550-1949) rule over the territory. The oldest literary evidence talks about the MPs in Kamrupa region are Alamgirinama (1337 CE ) and the account of Shihabuddin, a writer came with Aurangzeb's commander Mir Jumla,

\section{Discussion}

After the close observation of thin line between religion, ritual and magical activity I found that the concepts of phrased dichotomy or polarity between magic and religion are not well studied. Magic is not entirely distinct from religion but a form of ritual behaviour and thus always has an element of religions. Tough, nature of religion is repetitive and appear stable with respect to culture but it has evolutionary processes like other elements of society (Aldenderfer 1993; Schachner 2001). Though the practices are resistive against social changes in the due practice of by individual ideology, private feeling, socio-political needs make some change in the structure and method of practices (Rappaport 1979:1968; Aldenderfer 1993). The cultural historian describes the belief and ritual practices as an idea or mental constructs, and are plausibly questioned the very notion of the reconstruction or understanding such beliefs and mental constructs in absence of historical evidence or persuasive analogy.

But if consider religion and ritual as a part of cultural intangible heritage and tries to understand those mental constructs as a legacy of our ancestral practical belief and apply the post-processual approach to decode the ideas from the symbols and suggested meanings. As I earlier discussed the symbol are also materialised object and in absence material artefacts it provides a batter platform to understand the complex things. For example, The inadequacy of writing or absence of a script, make people communicate with the help sign language or via symbols. The privation in writing or dearth of the script might have forced sorcerers also to use symbols instead of a script (Fig. 20). But in the case of black magic symbols might have been also used for remembrance and keeping the knowledge restricted to a limited person or no open access to all. It will be very safe to call such belief as homoreligious belief because MMPs and MPs are prevalent and practised in almost every religion beyond the philosophical boundaries of the respective religion.

Nowadays the mystical practices seem to be profoundly swayed by the tantric credence present in prevalent 
religious practices of the geographical vicinity of global Mayong. This happens due to heterogeneity and crosscultural reproduction of belief system (in globalized era), devastating change in population and settlement pattern, the spread of education, use of magic for Murder and killing (India Today survey report between 2001- 2014) (Graph 1), improvement of the communication system and availability of modern technology and medical system.

Because globalization paved a porous way to open migration and free settlement and it has created an atmosphere of cultural heterogeneity it is challenging to identify the original as well as indigenous nature and structure of the current magical practices. The limited use and restricted to the handful of people make practices of magic inadequate to endure in the exclusive society. Though sometimes it is said that the practices are economically motivated but this did not negate the notion of religious beliefs. For example, one of the causes of the dogmatization of MMPs or MPs could be practice by economically motivated fake sorcerers (Fig.22)but when I analyse the situation historically in proper cultural context and social settings the religious movement like propagation of $\operatorname{Namghar}^{9}$ (Fig. 21), which very much criticised the code of necromancy and religious sacrifices played a major role in becoming a powerful antagonist to the ancient practice of black magic and witchcraft.

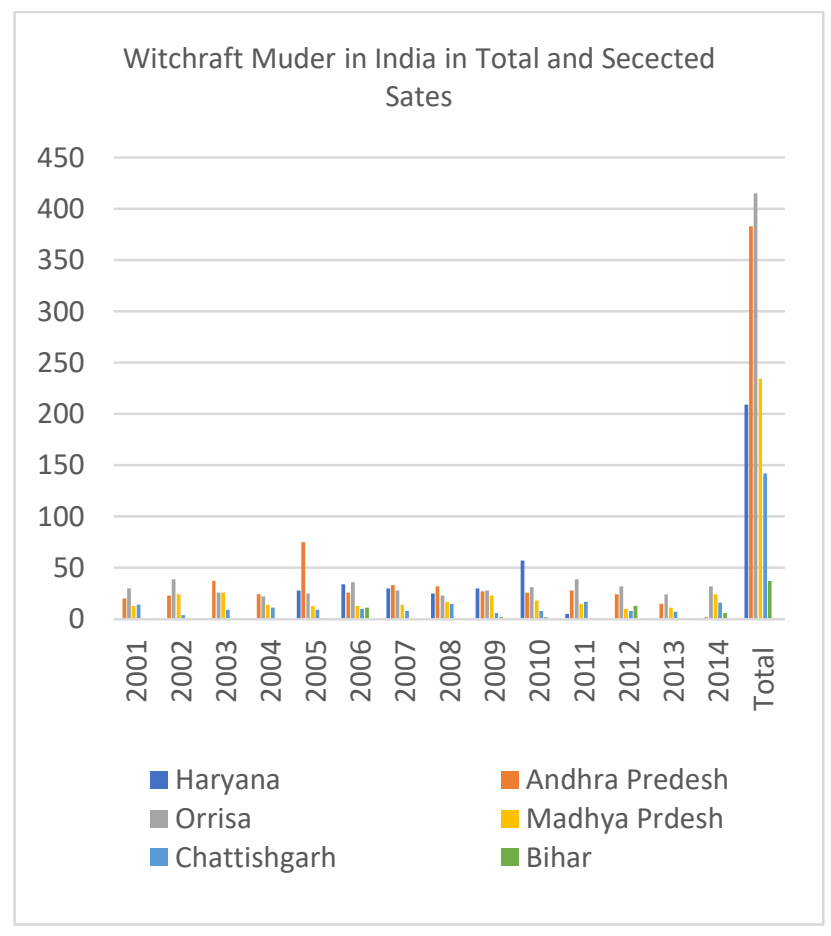

Graph- 1. Survey Report by India Today

\footnotetext{
${ }^{9}$ A prayer house of Ekasarana sect of Hinduism has played a vital role in reducing the perplex of veneration. Shankardeva (1448 CE-1568 CE) propagated the culture of Namghar in reaction to the ancient practice of black magic and witchcraft.
}

\section{Conclusion}

However, in the end, the proficiency of black magic as an agent for ethnic and language change is yet to be fully explored. It is required that the mystical practices must be approached in order to decode all the uses, meanings and underlying science of material culture and symbolism. It is essential to recognize the potentiality embedded in MMPs or MPs as a key factor of the development of cognitive belief system. There is also a need to focus on time as a mechanism for approaching the archaeology of black magic.

Black magic, as MMPs or MPs of cultural intangible heritage, must not be observed as a sinister to reverence and medical science. This research has made attempts to study these ritual practices as part of cultural intangible heritage through the ethnoarchaeological point of view and attempted to critically analyse the lacuna in approaching rituals and belief.

\section{Acknowledgement}

I am thankful to my guide Prof. Vasant S. Shinde, ExVice chancellor, Deccan College Post Graduate and Research Institute for the constant support and encouragement.

\section{References Cited}

Aldenderfer, Mark 1993. Ritual, Hierarchy, and Change in Foraging Societies. Journal of Anthropological Archaeology, Vol. 12, p1-40.

Baglari, M. Happy, 2015. The Magic Art of Witchcraft and Black Magic, International Journal of Scientific and Research Publications, Volume 5.

Barua, B. K. 1950. Sorcery and its Practices in Assam, Journal of the University of Guwahati, Vol. I, No. 1

Barua, N.N. 1982. Dimasa Sakalar Geet Mat, Guwahati.

Baumer, Christopher 2002. Bon: Tibet's Ancient Religion., Weatherhill; y

Bellezza, John Vincent 2005. Spirit Mediums, Sacred Mountains and Related Bön Textual Traditions in Upper Tibet, Boston: Brill.

Bird-David, Nurit 2000. "Animism" Revisited: Personhood, Environment, and Relational Epistemology". Current Anthropology. 41 (S1), p 6791

Blythin, Islwyn 1970. Magic and Methodology Num. Vol. 17, Fasc. Published by: Brill. 
Bruckner, Heidrun 1987. Bhuta Worship in Coastal Karnataka: An Oral Tulu Myth and Festival Ritual of Jumadi. Studien zur Indologie und Iranistik. 13/14.

Casson Lionel 1989.The Periplus Maris Erythraei: Text with Introduction, Translation and Commentary, Princeton University Press.

Caudhurī, Niśipada 1985. Historical archaeology of central Assam, Delhi: B.R. Pub. Corp.; New Delhi, India: Distributed by D.K. Publishers' Distributors, p.2

Choudhury, Pratap Chandra 1959. The history of the civilisation of the people of Assam to the twelfth century, Gauhati: Dept. of Historical and Antiquarian Studies in Assam, Page 448,

Clifford, Andrew 2012 The Geological Model for Religion.

Das, Jogesh 1972. Folklore of Mayong. National Book Trust, New Delhi.

Das, M. 1988. Dakhin Kamrupar Loka Biswas aru Jana Sanskar Palas Uari.

DeMarrais, Elizabeth et al. 1996. Ideology, Materialization, and Power Strategies, Current Anthropology, Vol. 37, No. 1, pp. 15-31.

Dhavalikar, M. K. 1973. Archaeological Excavations, Bulletin of the Deccan College Post-Graduate and Research Institute, Vol. 33, No. 1/4, pp. 41-76

Dhavaliker et al. 1971. Inamgaon: A Chalcolithic Settlement in Western India, Asian Perspectives, Vol. 14, pp. 139-146.

Dunn, Patrick 2005. Postmodern Magic: The Art of Magic in the Information, Llewellyn Publications

Durkheim, Emile 1976, 1912. The Elementary Forms of the religious Life. 2nd ed. Allen and Unwin, London.

Elliot and G. Smith 1924. Medicine, Magic, and Religion. London.

Evans-Pritchard, E.E. 1965, The Theories of Primitive Religion. Oxford.

Fogelin, Lars 2007. The Archaeology of Religious Ritual, Annu. Rev. Anthropology, Vol. 36 p55-71.

Frazer, James G. 1922, The Golden Bough London.

Garg, Ganga Ram 1992. Encyclopaedia of the Hindu World, Concept Publishing Company, p 428.

Goswami, K. P. 1998. Kamakhya Temple- Past and Present. 5, Ansari Road, Darya Ganj, New Delhi: A.P.H. Publishing Corporation, p 25.

Harari, Yuval Noah 2014. Sapiens: A Brief History of Humankind Hervill Seeker publication.
Hicks, David 2010. Ritual and Belief: Readings in the Anthropology of Religion (3 ed.).Rowman Altamira, p359.

Hofstede, Greet 1980 Culture's Consequences: International Differences in Work-Related

Howey, Meghan C. L. and O'Shea, John 2009. On Archaeology and the Study of Ritual: Considering Inadequacies in the Culture-History Approach and Quests for Internal "Meaning", American Antiquity, Vol. 74, No. 1, pp. 193-201

Hunter, D and P. Whitten 1977. The Study of Cultural Anthropology, New York.

Hussain, A. 1982. The National Culture of India, Delhi.

Hutton, Ronald 1999. The Triumph of the Moon: A History of Modern Pagan Witchcraft, Oxford University Press.

Insoll, Timothy 2004. Archaeology, ritual, religion Routledge Taylor and Francis Group

Insoll, Timothy 2009. Materiality, Belief, Ritual Archaeology and Material Religion: An Introduction, Manuscript Mater Relig. November 1; 5(3): 260-264.

Jameson, Fredric 1991 Postmodernism or, The Cultural Logic of Late Capitalism. Durham: Duke University Press, p. 16

Kalita, Dilip Kumar 1992. A study of the magical beliefs and practices in Assam with special reference to the magical lore of Mayong, Unpublished PhD dissertation, Guwahati University.

Levy-Bruhl, Lucien. 1926. How Natives Thinks. London. New York.

Malinowski, Bronislaw. 1940. Magic, Science and Religion and Other. The Free Press: Glencoe, Illinois.

Malinowski, Bronislaw. 1995. Corals Gardens and Their Magic, vols.2 London.

Manuel, Castells 1996. The information age: economy, society and culture. Oxford: Blackwell.

Morrisson, Mark S. 2017. The Periodical Culture of the Occult Revival: Esoteric Wisdom and Counter-Public Spheres Journal of Modern Literature, Vol.31, No. 2 (Winter, 2008), Published by Indiana University Press.

Nanda, G. C. 2014 Mayong: The Heritage of Black Magic and Traditional Treatment Insp. Res. Ayurveda pharm, Vol. 5 (2).

Nath, Bhrigu and Bhattacharya, Prasanta 2016 Development of Eco-Tourism and Panorama of Rural Tourism in Pabitora- Mayong Area, Assam, India International Journal of Interdisciplinary Research in Science Society and Culture(IIRC) Vol: 2, Issue:1, (June Issue). 
Nath, R.M. 1948. The Background of Assamese Culture, Guwahati. Published by: Brill.

Puri, Baij Nath 1968. Studies in Early History and Administration in Assam, Gauhati University

Rajkhowa, B. 1973 Assamese popular Superstitions and Assamese Demonology, Guwahati University.

Rappaport RA. 1968. Pigs for the Ancestors. New Haven: Yale Univ. Press

Rappaport RA. 1979. Ritual regulation of environmental relations among a New Guinea people. In Ecology, Meaning, and Religion, Berkeley, CA: N. Atl. Books

Read, C 1925. Man, and His Superstitions, Cambridge University Press.

Rehman, Iqra and Mohyuddin, Anwaar 2015. Impact of Blackmagic and Witchcraft in Mystic Thoughts. Research Journal of Sufism and Peace Supplementary Edition Vol. I.

Ries. J 1944. The origin of religion. US: Eerdmans Publication Corporation

Robb JE, ed. 1999. Material Symbols: Culture and Economy in Prehistory. Carbondale, IL: Cent. Archaeol. Investig

Robb JE. 1998. The archaeology of symbols. Annu. Rev. Anthropol. 27:329-46

Rosengren, Karl Erik et. al 1976. Malinowski's Magic: The Riddle of the Empty Cell [and Comments and Reply], Current Anthropology, Vol. 17, No. 4, pp. 667685.

Rout.J and A. Sajem 2000. Some Superstitious Botanical Folklore of Different Tribes of North Cachar Hill. Assam (North-East India), Assam University.

Sarkar, J. N. 1992. "Chapter II The Turko-Afghan Invasions", in Barpujari, H. K. (ed.), The Comprehensive History of Assam, 2, Guwahati: Assam Publication Board, pp. 35-48

Sarma, N.C. 1988. Essays on the Folklore of North-East India, Guwahati.

Schachner, Gregson 2001 Ritual Control and Transformation in Middle-Range Societies: An Example from the American Southwest, Journal of Anthropological Archaeology, Vol. 20,p168-194.

Singh, Upinder 2009. A History of Ancient and Early Medieval India. Person Publication.
Sircar, D C 1990. "Political History", in Barpujari, H $K$ (ed.), The Comprehensive History of Assam, I, Guwahati: Publication Board, Assam, pp. 94-171

Sircar, D C 1990. "Pragjyotisha-Kamarupa", in Barpujari, H K (ed.), The Comprehensive History of Assam, I, Guwahati: Publication Board, Assam, pp. 5978

Sperber, D. 1975. Rethinking Symbolism New York: Cambridge University Press.

Sperber, D. 1985. Anthropology and psychology: Towards an epidemiology of representations.

Spradly, J.P. and D.W. McCurdy 1975. Anthropology the Cultural Perspective, New York.

Stutley, M. 1980. Ancient Indian Magic and Folklore, Rutledge and Kegan Paul, London.

Tylor, E.B. 1867, Phenomena of the Higher civilization: Traceable to a Rudimental Origin Savage Tribes Anthropological Review. 5: 303-314.

UNESCO 2012. Operational Guidelines for the Implementation of the World Heritage Convention, UNESCO World Heritage Centre. Paris. Page 14

Valk, Ulo and Neelakshi Goswami 2013. Generic Resource and Social Boundaries of Magic Assam Field Nature Note from Assam. Journal of Folkloristics, Vol-1. Values. Sage Publication Landon, New Delhi and Newbury Park.

Webber, E. Robert 2006. The Divine Embrace recovering the passionate spiritual life. Baker Books Grand Rapid, Michigan.

Webster, H. 1948. Magic a Sociological Study, London.

Wheeler, M. 1983. 'India', Man, Myth and Magic, ed. $R$, Cavendish, New York.

Wilce, James M. 2005. Traditional Laments and Postmodern Regrets: The Circulation of Discourse in Metacultural, Journal of Linguistic Anthropology, Vol. 15, No. 1, Special Issue: Discourse across Speech Events: Intertextuality and Interdiscursivity in Social Life, pp. 60-71

Wilki, L.A. 1995. Magic and Empowerment of Plantation: An Archaeological Consideration on African -American World View, South Asian Archaeology vol. 14, no. 2, winter. 


\section{List of Figures}

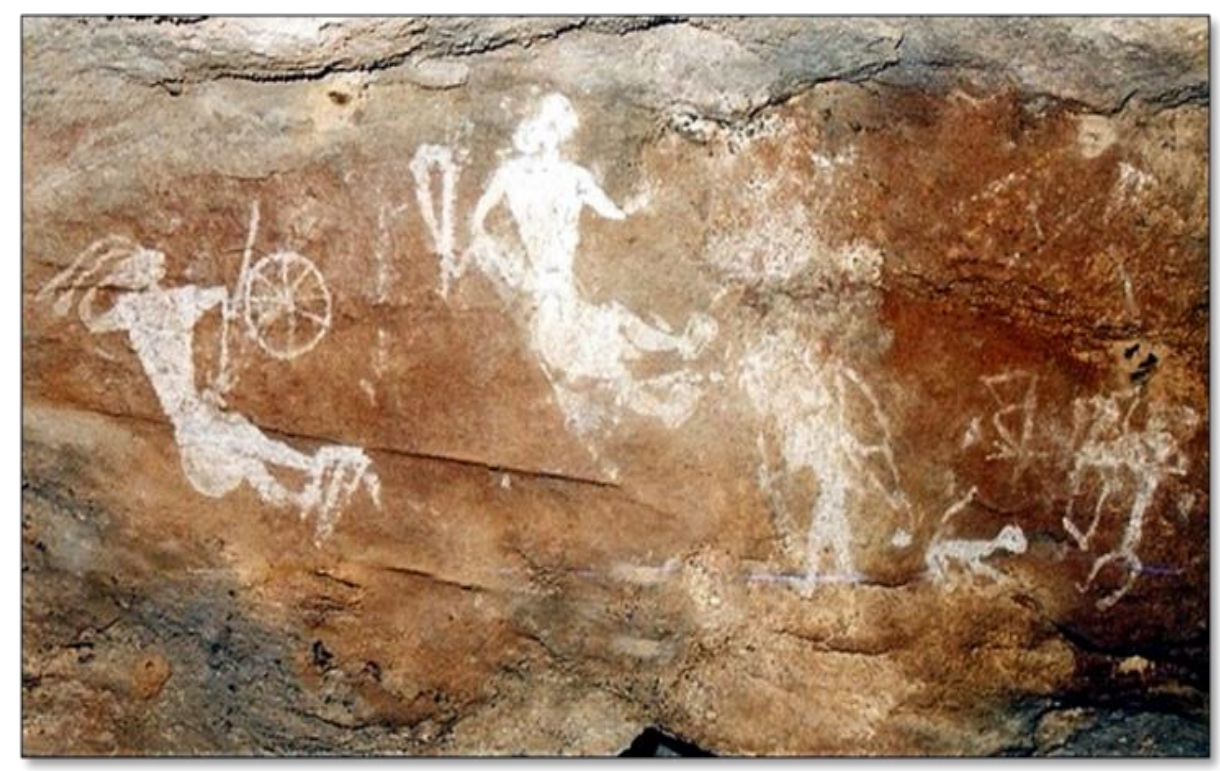

Fig. 1 six-armed chakra along with animal-headed spirit with Puthi from Pachmarhi hill, Madhya Pradesh

Courtesy: http://www.bradshawfoundation.com/india

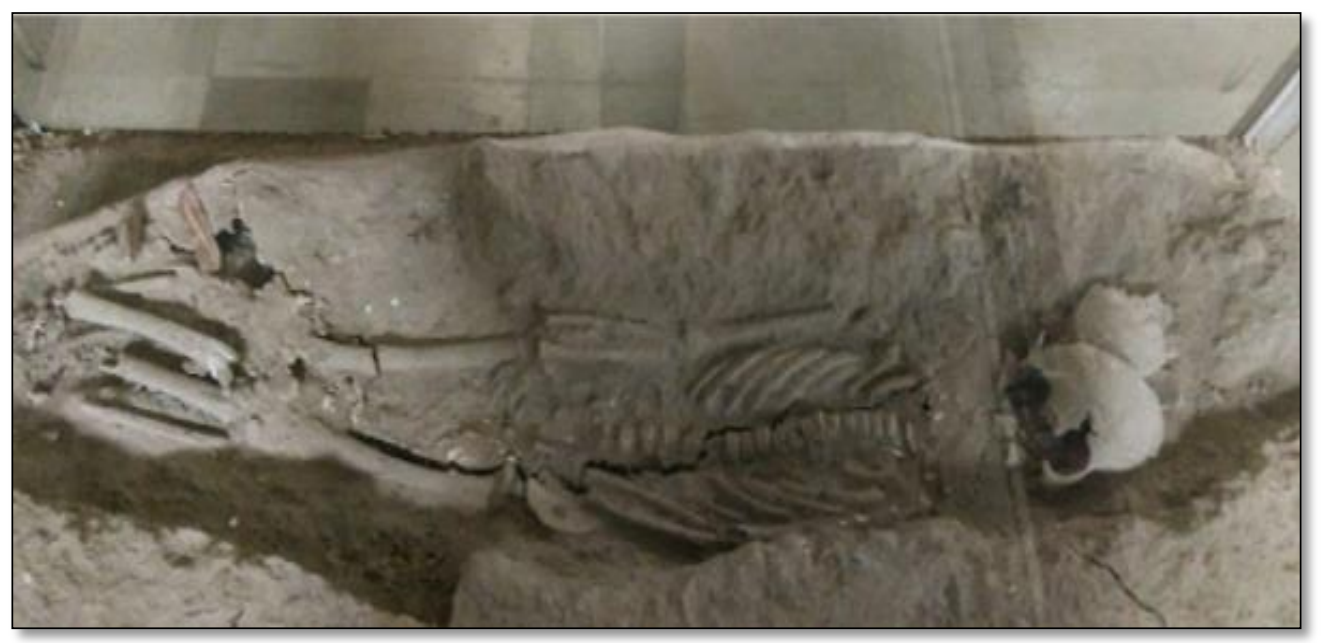

Fig. 2 Inamgaon extended burial of period II (1400-1100 BCE) 


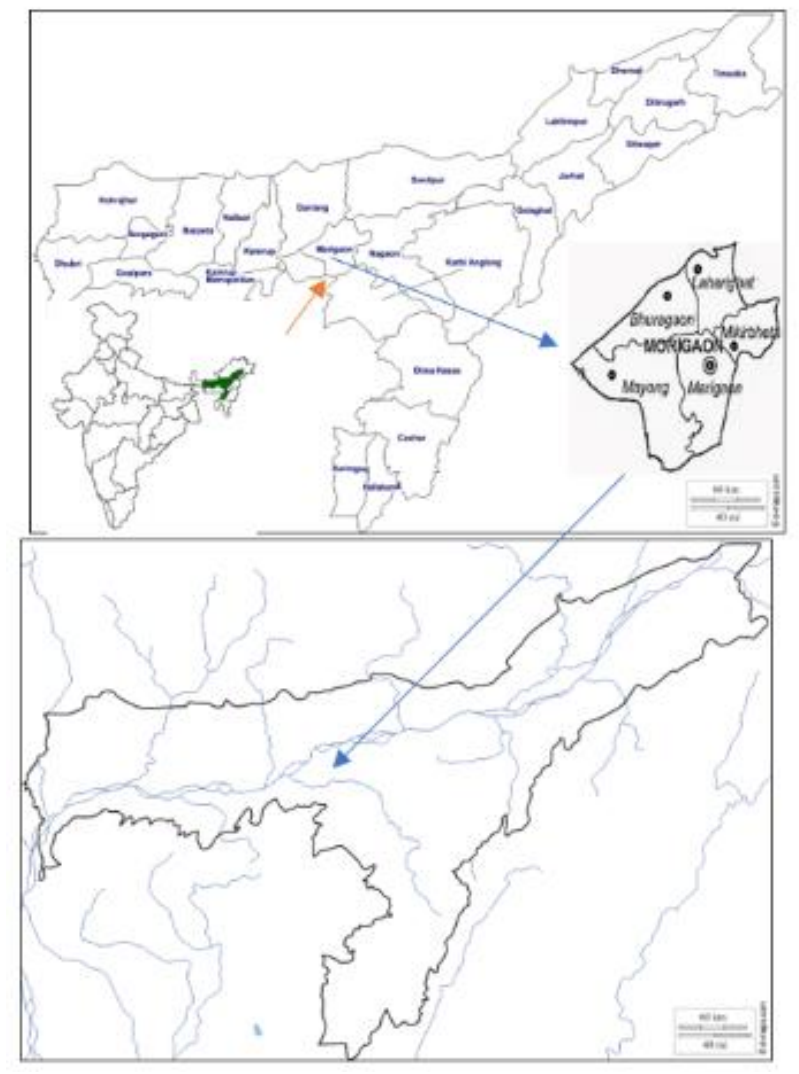

Fig. 3 Physical Map of geographical vicinity of village Mayong

Courtesy: https://lh3.googleusercontent.com/dqiYd1

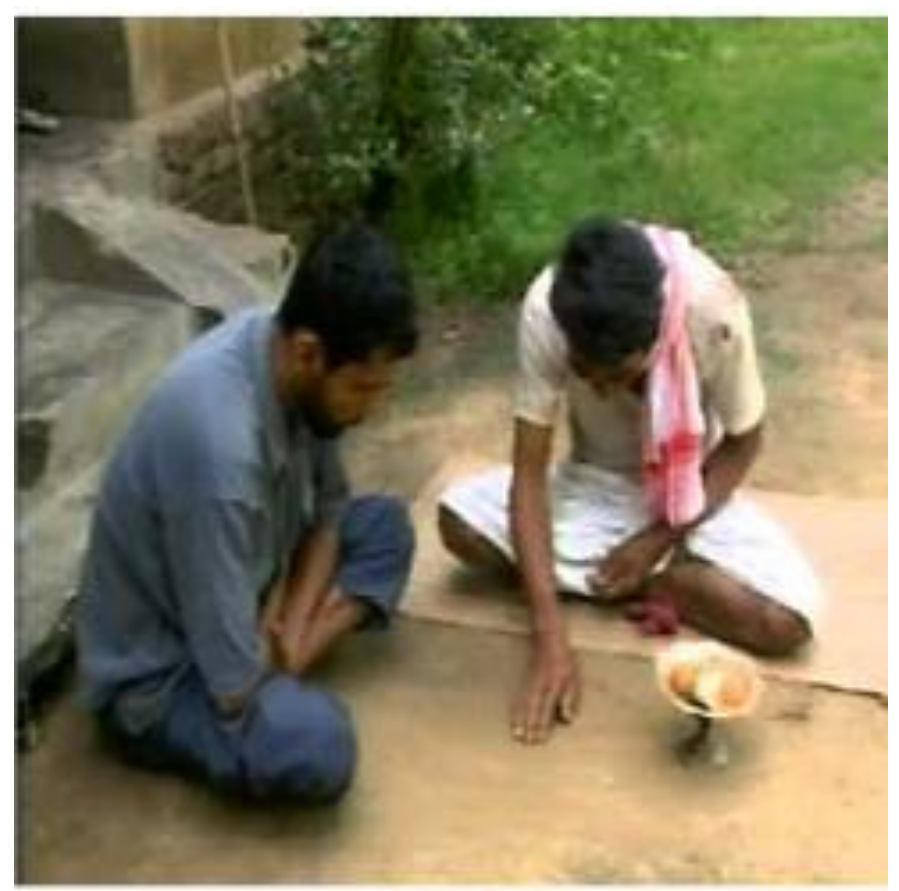

Fig. 4 Predicting Future with the help of Korris (Cowrie seashells) at Mayong, Assam Courtesy: https://www.storypick.com/ 


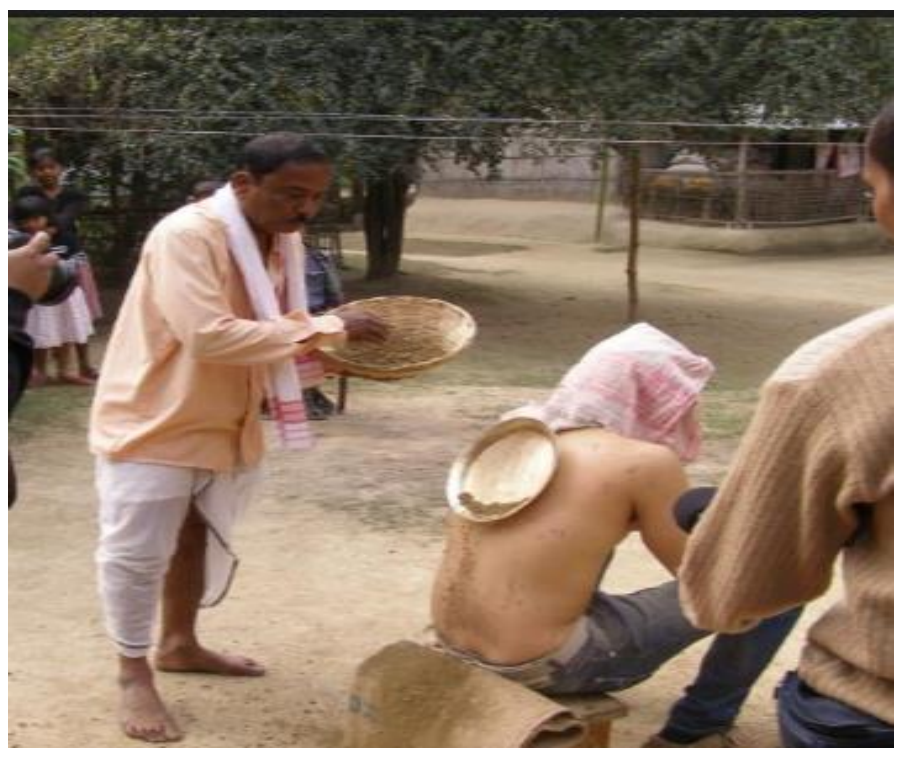

Fig. 5 Treatment of back pain by enchantments and copper dish in Mayong, Assam Courtesy: http://reviewne.com

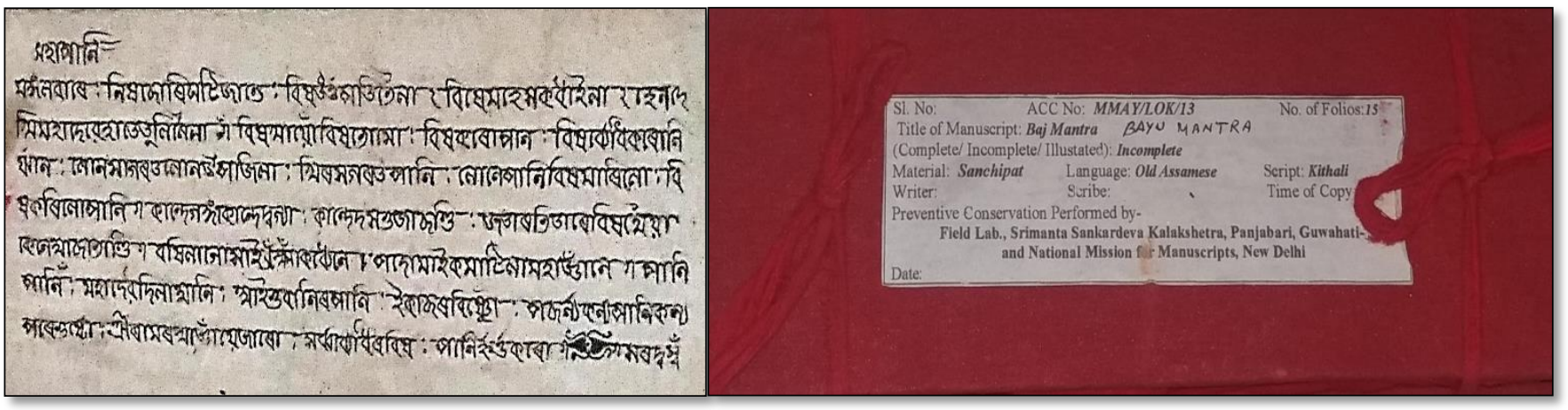

Fig. 6 Old Assamese language and Kithali script of manuscript Mayong, Assam

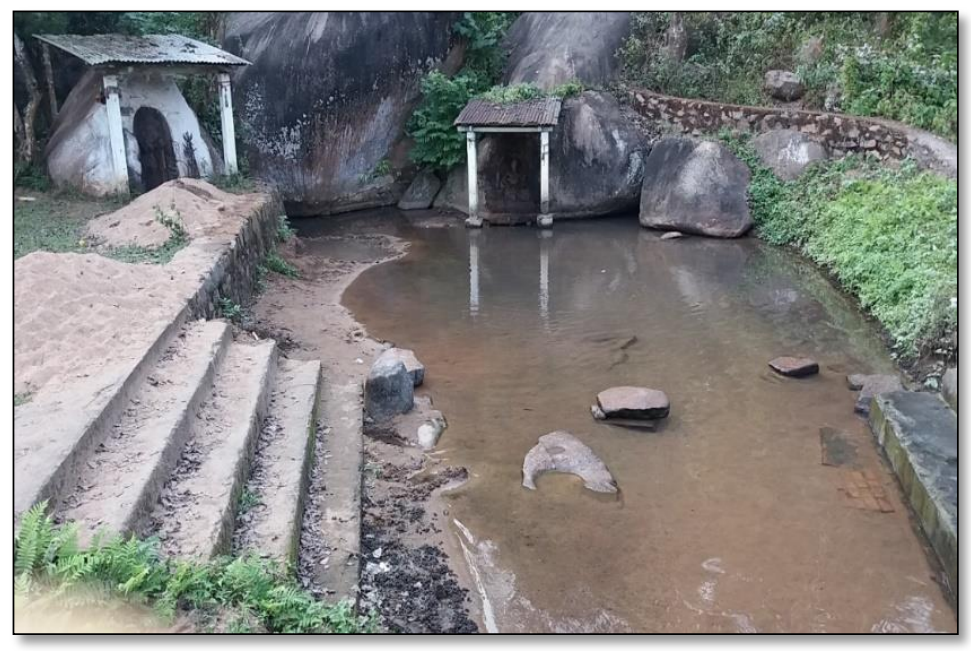

Fig.7 Carving of Ganesha and Har-Gaudi accordingly the story of Shiva Puran in front of Kesaikhati than, Mayong, Assam 


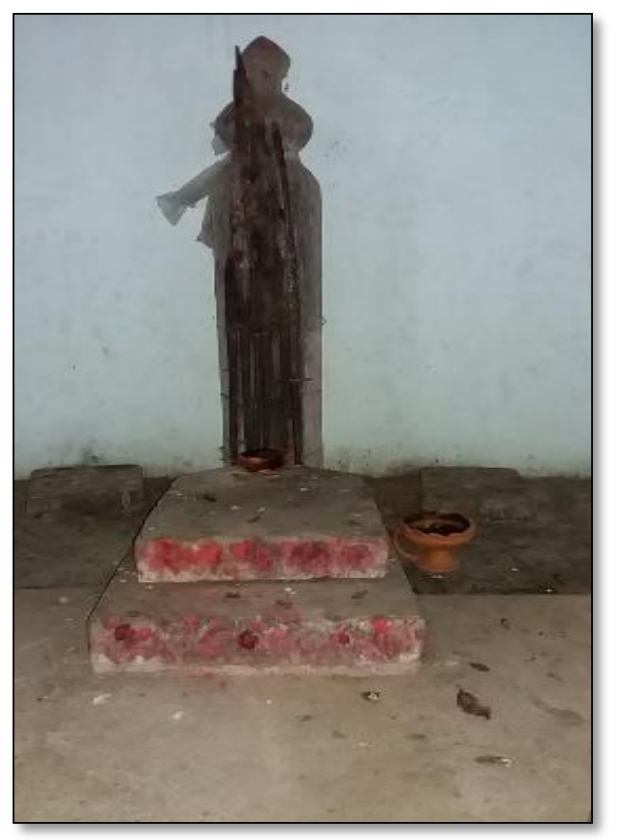

Fig. 8 Sacrificial post with swords in Kesaikhati than, Mayong, Assam

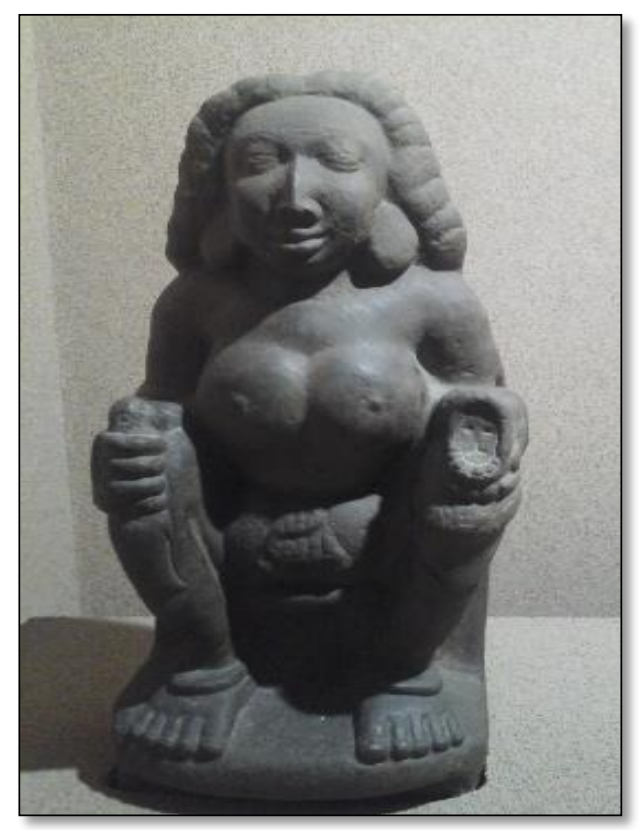

Fig. 9 Unidentified sculpture related to practice of necromancy from Ambari, Guwahati, Assam (10th - 12th cen. CE) 


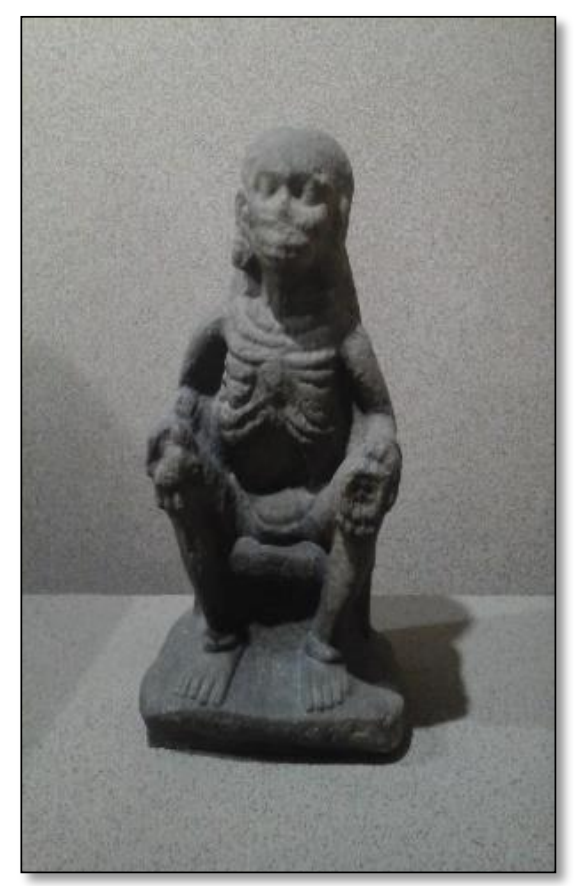

Fig. 10 Mysterious sculpture, representing the practice of necromancy from Ambari, Guwahati, Assam (10th - 12th cen. CE)

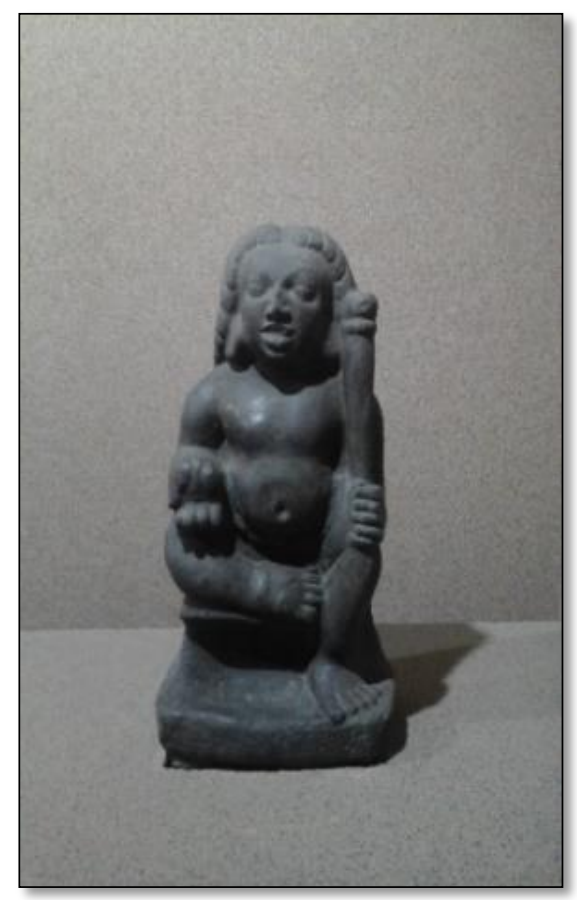

Fig. 12 Anonymous sculpture associated to the practice of necromancy from Ambari, Guwahati, Assam (10th - 12th cen. CE) 


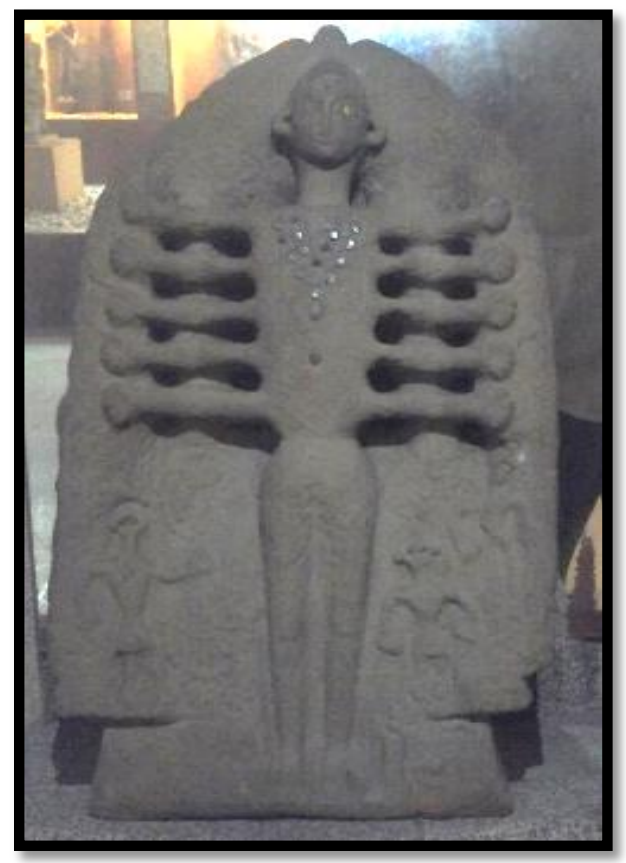

Fig. 13 Tribal form of Durga from Mangaldoi, Assam

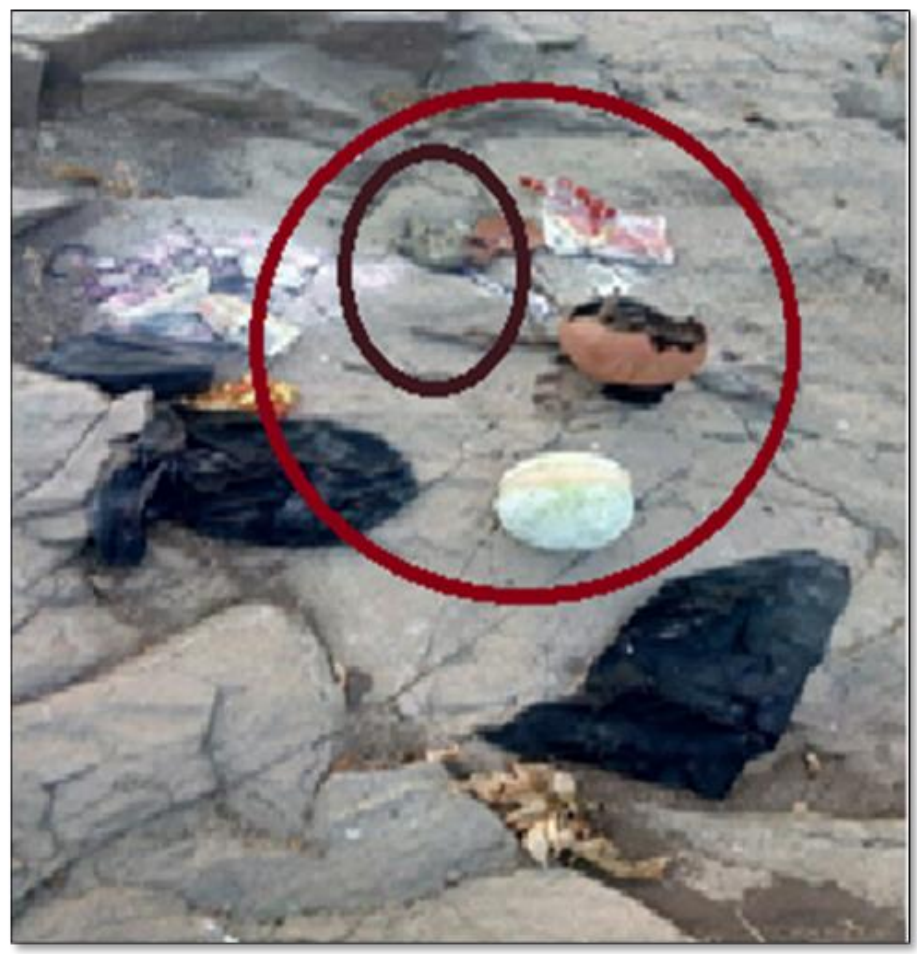

Fig. 11 Evidence of contemporary black magic material, Pune 


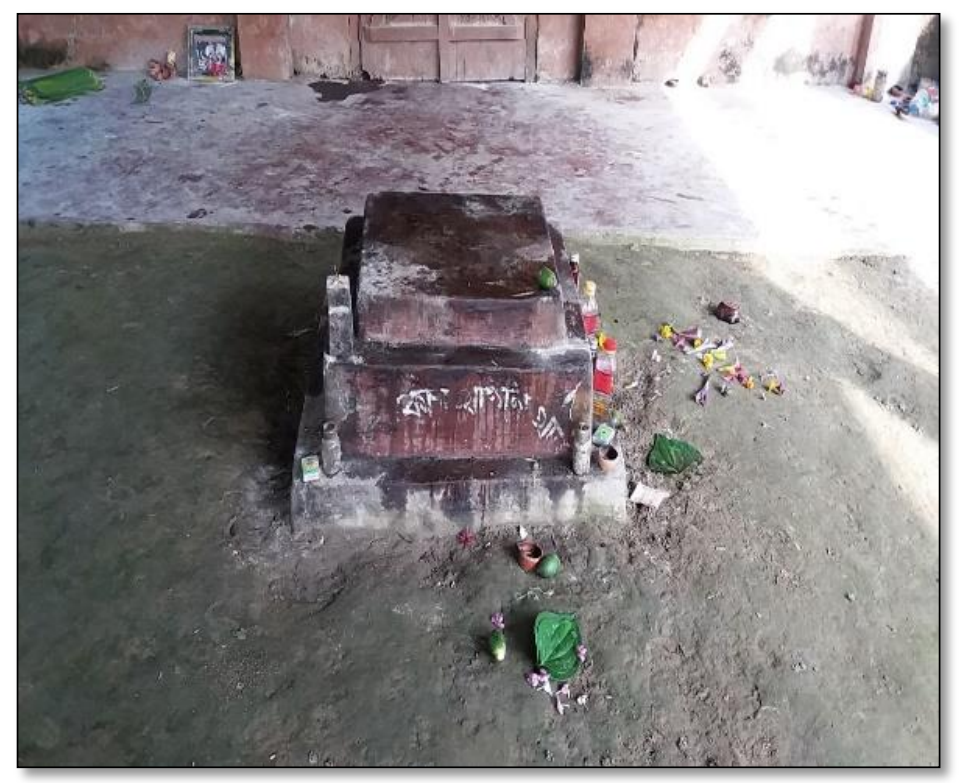

Fig. 14 Sacrificial place of Kali than temple of Mayong, Assam
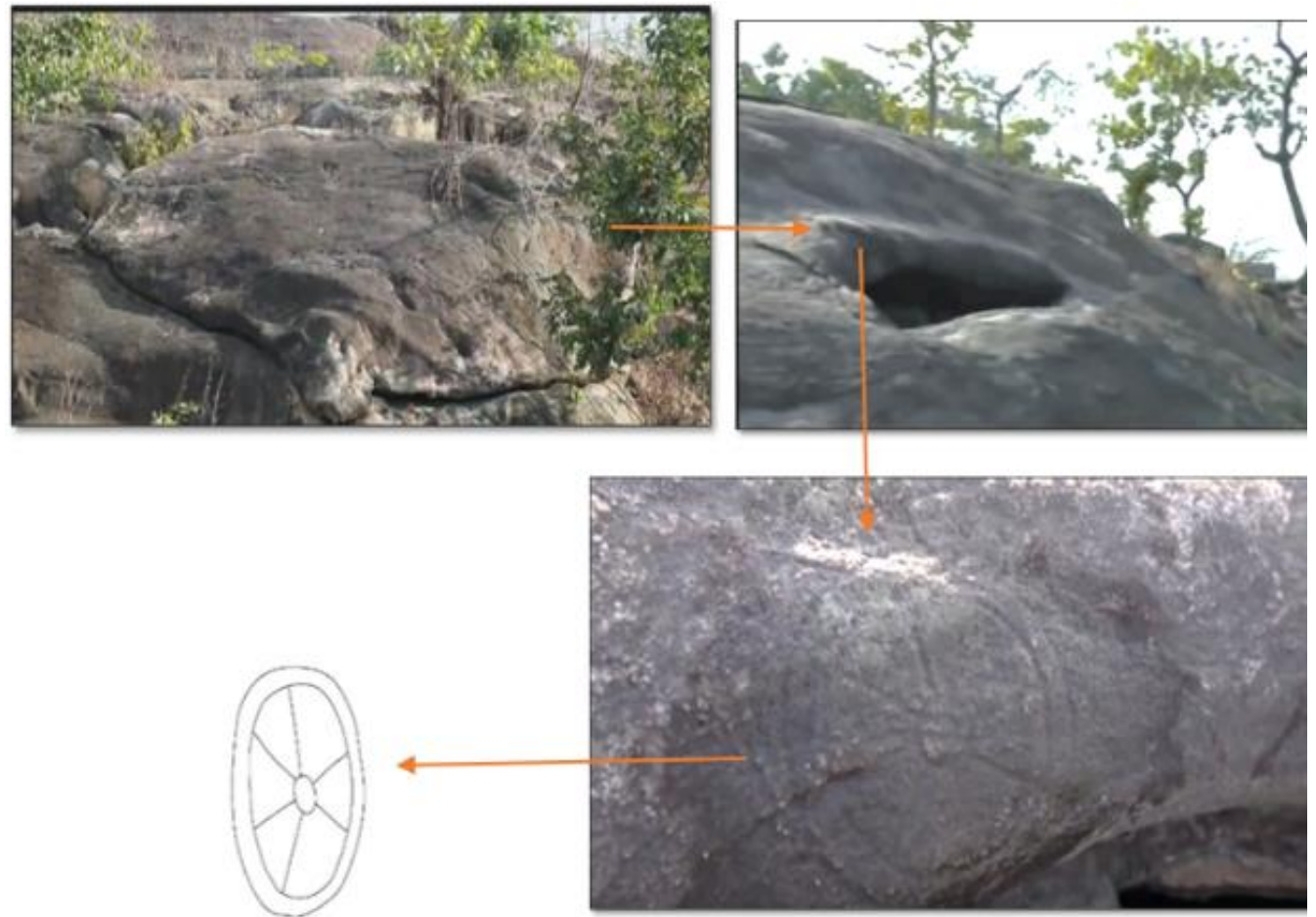

Fig. 15 Depiction of Chakra on Yoni Kund, Mayong, Assam 

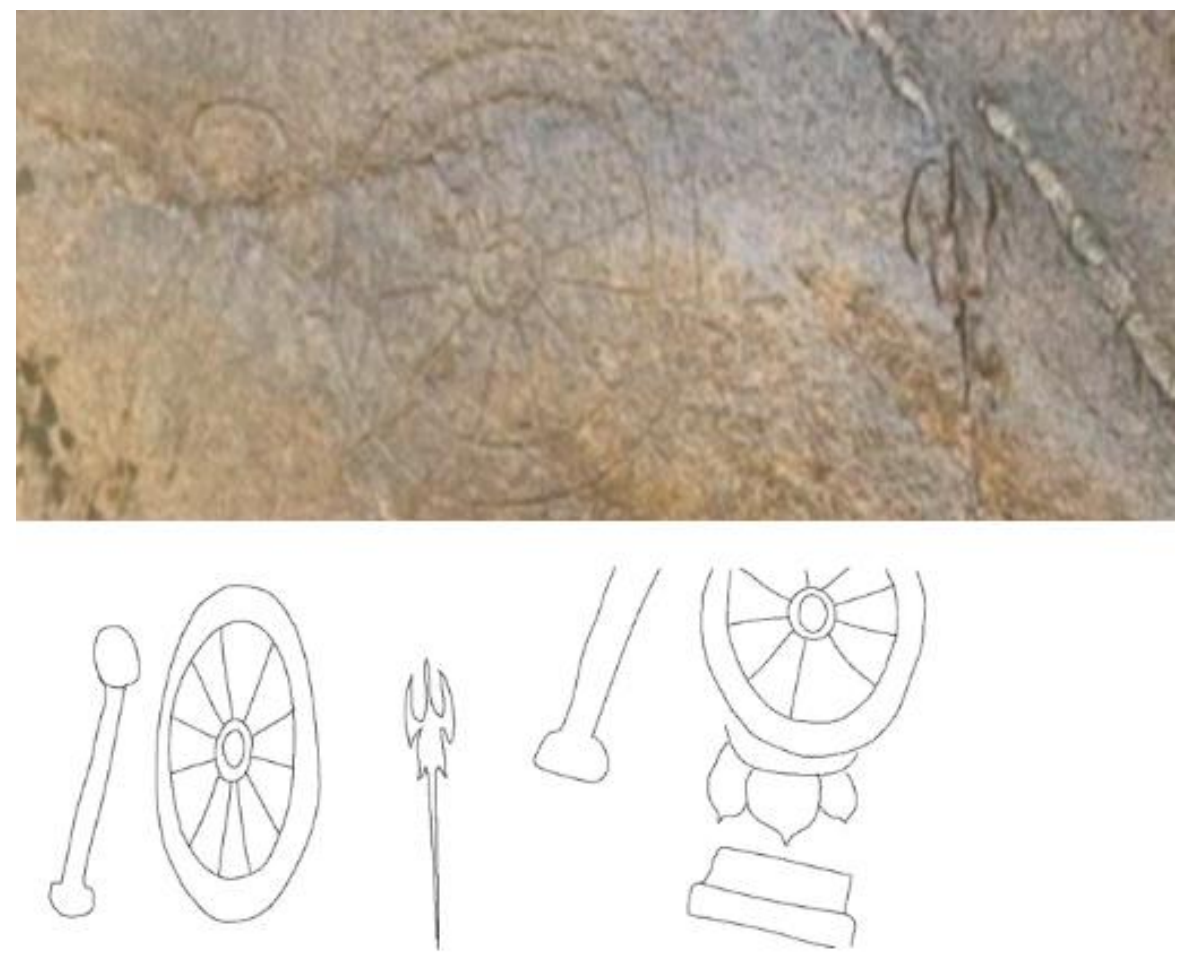

Fig. 16 Symbol of chakra along with trident and bones on Kachoxila, Mayong, Assam
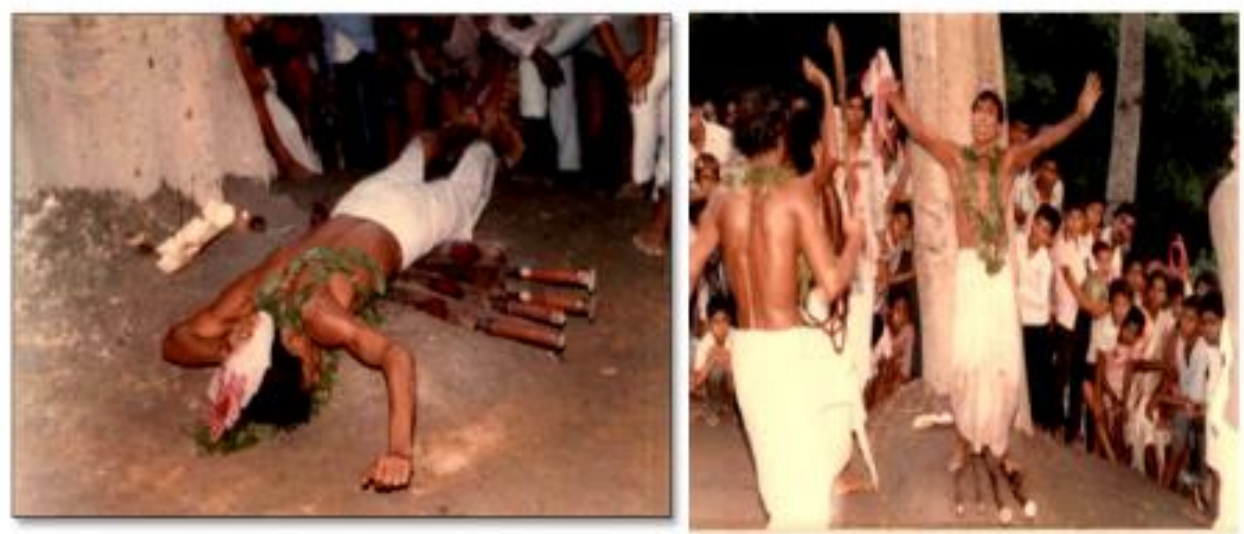

Fig. 17 Use of swords in possession Courtesy: Kalita (1992) 


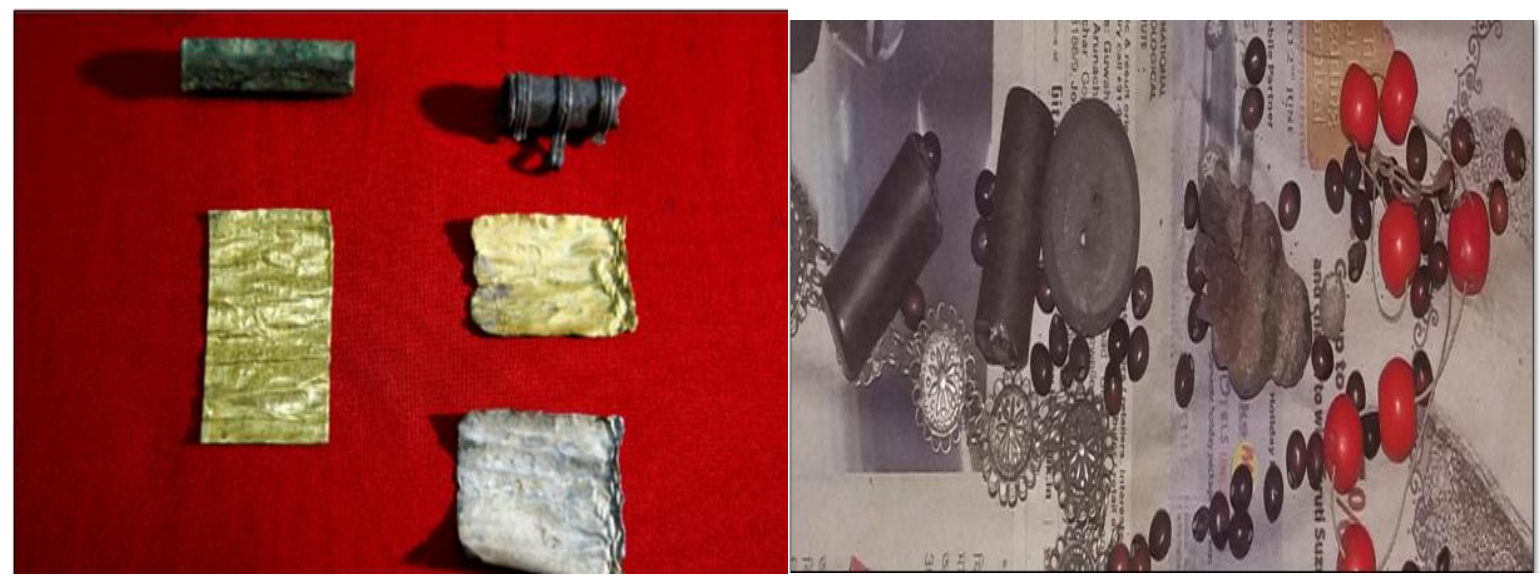

Fig. 18 Use of swords in possession Courtesy: Kalita (1992)
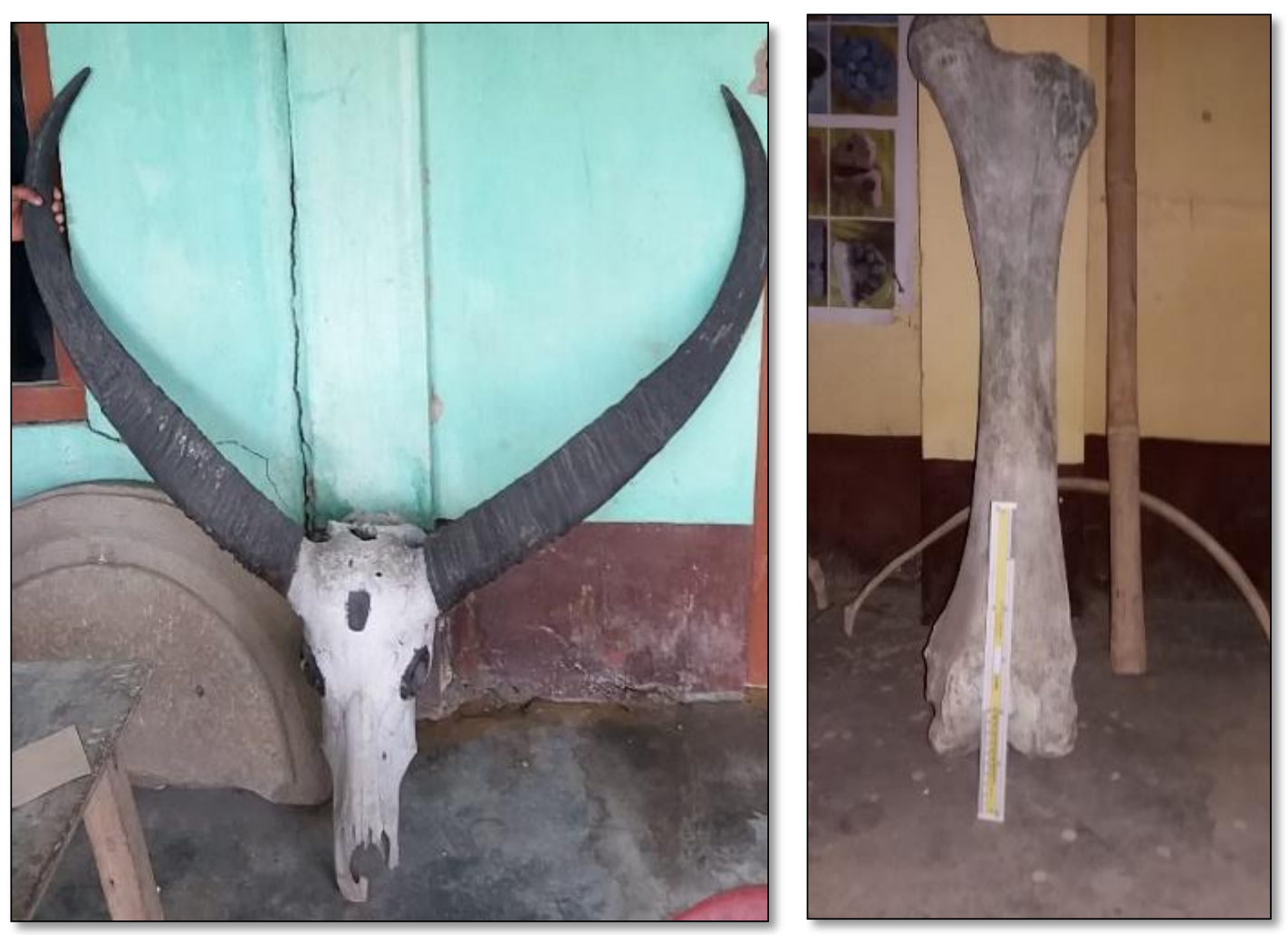

Fig. 19 Head \& Femur of cattle 


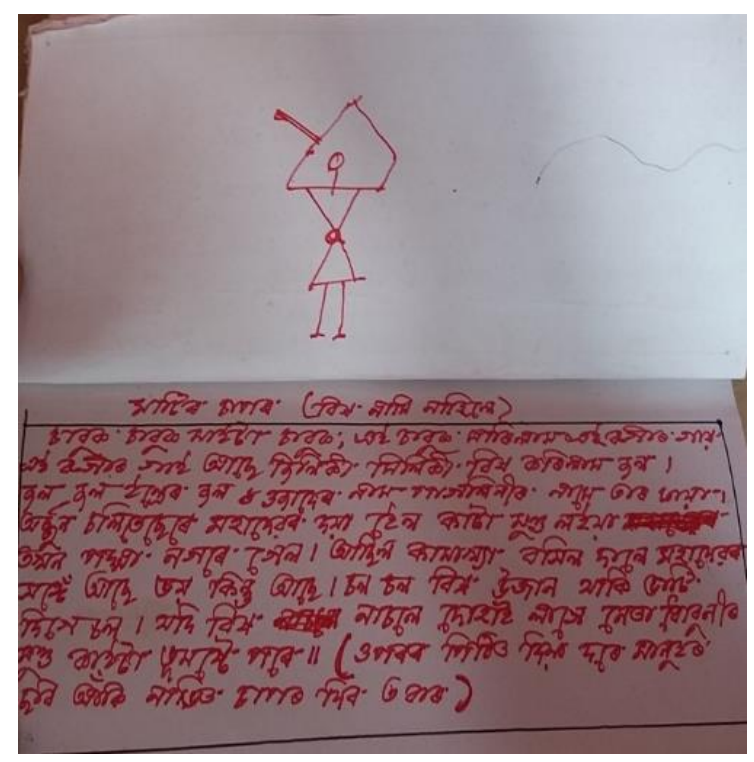

Fig. 20 Use of symbol as a tool for remembrance of mantra

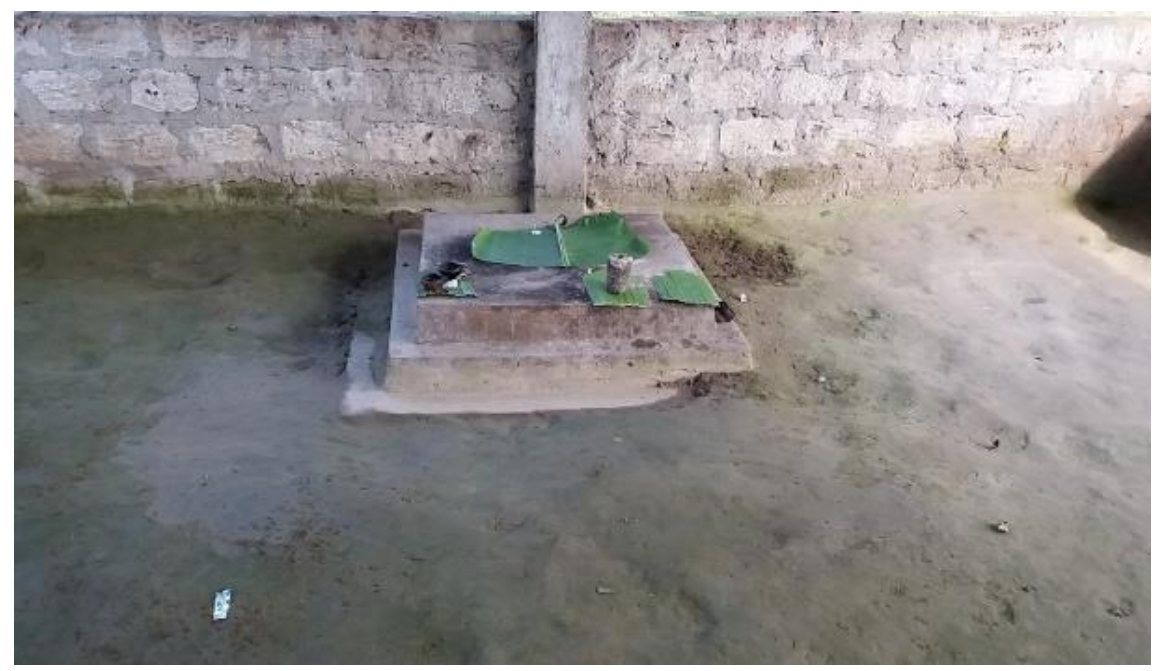

Fig. 21 Namghar at Mayong, Assam

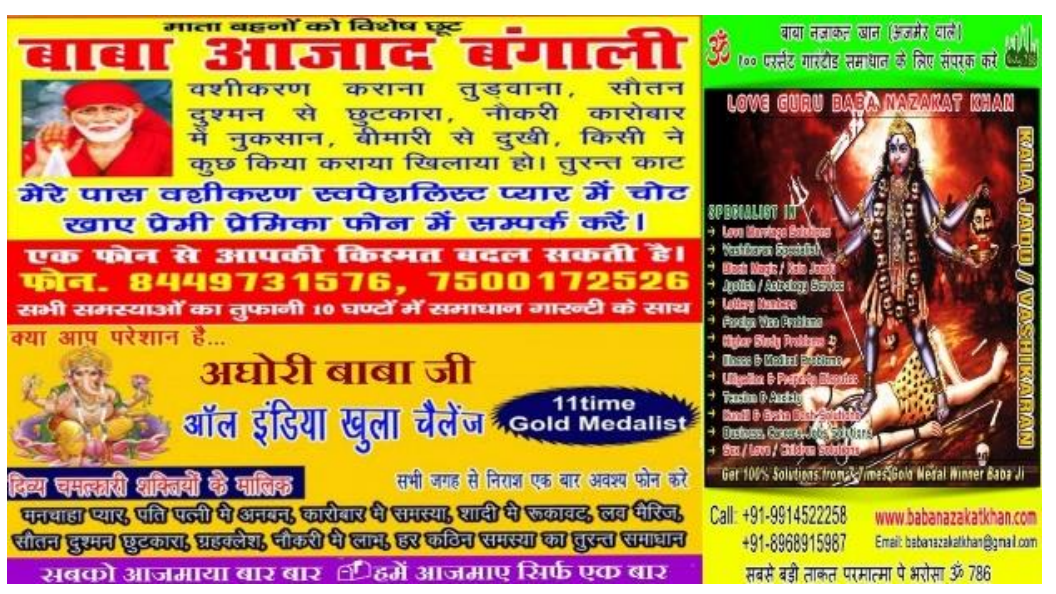

Fig. 22 Posters of magician 